\title{
Die Belydenis in dogmatiese verband
}

\section{GC Velthuysen}

Om die verband tussen die kerklike belydenis en die dogmatiek aan te dui is nie so 'n eenvoudige en vanselfsprekende saak as wat mens geneigd sou wees om te dink nie. Inteendeel, dit is 'n hoogs ingewikkelde aangeleentheid. Daarom moet mens dit nie nog moeiliker maak deur toe te laat dat begripsverwarring jou op ' $n$ dwaalspoor bring nie. Daar moet, voordat daar enigsins verder beweeg word, eers duidelikheid verkry word oor wat elkeen van hierdie begrippe impliseer en met watter betekenisinhoud hulle in hierdie voordrag gebruik sal word.

Kom ons dink daaraan dat die woord "belydenis" byvoorbeeld, nie vir elkeen wat dit gebruik presies dieselfde sê nie. Vir die een is dit die lewende getuienis van die kerk in die situasie waarin hy hom bevind. Vir die volgende een is dit die gefikseerde (mondeling oorgelewer ò skriftelik) leer van die kerk. Vir nog 'n derde is dit albei hierdie moontlikhede. Die één verstaan dit positief - as uitdrukking van die hartklop van die geloof van die kerk, as waarborg van eenheid en waaragtigheid. Vir die ander een het die woord 'n uiters negatiewe konnotasie, en roep dit beelde op van verstarring en steriliteit.

Dieselfde soort ding is waar van die woord "dogmatiek". Vir sommige impliseer hierdie woord niks meer nie as 'n beskrywing en ontleding van die dogmas van die kerk. Hiervolgens is die taak van die dogmatiek die handhawing en deurgee van dit wat vroeër reeds vasgelê is. Vir 'n ander een weer, impliseer hierdie woord daardie werksaamheid waardeur dogmas geskep word. 'n Derde een weer sal die woord verstaan as 'n heenwysing na daardie wetenskap waardeur die kerk kom tot 'n verantwoodelike teologiese antwoord op die appél vanuit die situasie waarin hy hom bevind. Die veronderstelling in hierdie verband is dat die dogmatiek, in die soektog na hierdie antwoord, Bybelse stof sal sistematiseer. Daar is egter ook 'n beskouing wat genoeë daarmee neem dat bykans enige ander materiaal verwerk word.

Met al hierdie moontlikhede in gedagte blyk dit dus noodsaaklik dat 'n nadere begripsbepaling eers gemaak sal word.

\section{BELYDENIS}

Wat was eerste, die belydenis as daad, of die belydenis as saak? Is daar eers bely, sodat die belydenis op grond van hierdie daad van belydenis tot stand gekom het; of was die belydenis as geopen- 
baarde saak daar, wat net bely moes word? Hierdie is nie so 'n belaglike vraag as wat dit by eerste waarneming mag voorkom nie. Inteendeel, dit is uiters belangrik. Reg verstaan lê die hele verskil tussen Rome en Reformasie opgesluit in die antwoord wat op hierdie vraag gegee sal word. Dink daaraan, as die inhoud van die belydenis geopenbaar is; as dit geopenbaar is as ' $n$ Waarheid, sodat die belydenis as daad niks meer kan wees as die nasê van dit wat eens en vir altyd volmaak gesê is nie, is dit tog duidelik dat die belydenis as saak - daardie gefikseerde belydenis - onaantasbaar en onveranderlik is, ' $n$ ewige waarheid in die volle sin van die woord. Aan die ander kant behoort dit duidelik te wees dat, as die daad van belydenis voorop staan, en die gefikseerde belydenis net verstaan word as uitdrukking van die stand van lewende belydenis op 'n bepaalde tydstip in die geskiedenis van die kerk - die belydenis as saak steeds prinsipieel aantasbaar en veranderlik sal wees.

'n Goeie punt waarvandaan vertrek kan word is die vraag: Wat is geopenbaar! 'n Oomblik se oorweging behoort dit dan ook duidelik te maak dat die vraag só eintlik verkeerd gestel is. Daar moet liewers gevra word: Wie het Hom geopenbaar? Want die Skrifte laat net een antwoord toe: God het Homself in sy liefde tot die mense geopenbaar. In die mens Jesus van Nasaret het Hy aan ons sy gesig gewys. Ons kyk na die mens Jesus van Nasaret, na wat Hy doen en sê, na hoe Hy ís, na sy ware liefde vir mense, sy barmhartigheid, sy bereidheid om te help, sy diensvaardigheid; en ons weet, só is God, Wie hierdie man sien, sien die Vader wat Hom gestuur het. Wie na Hom luister, luister na die Vader. Sodoende leer ons Hom dan ken, die Drie-enige God, wat ons deur sy Woord en Gees leer wat daar in sy hart leef en wat Hy met ons en ons wêreld in die oog het.

Dit is die Waarheid wat aan ons geopenbaar is. Dit is nie ' $n$ abstrakte ewige Waarheid nie, maar 'n Persoon. Hierdie Persoon roep om 'n beslissing: "Wie is Ek?" "Wie sê die mense is Ek?" "Wie sê julle is Ek?" Die antwoord het nie uitgebly nie. Hy is aangedui as profeet, malman, tollenaarsvriend, vraat en wynsuiper; maar óók as die Seun van God, as die Christus, as die Here. Laasgenoemde antwoorde was geloofsantwoorde. Dit was die antwoorde van mense wat in Hom geglo het, vir wie Hy meer was as ' $n$ besondere mens, mense wie se oë dermate deur die Gees geopen is dat hulle in Hom die Heiland van die wêreld herken het. Dit is 'n werklikheid wat hulle in hulle eksistensie aangryp. Hulle kan nie anders nie, hulle jubel dit uit: "Jesus Christus is Here!" (Fil 2:11) Hulle bely hulle geloof in Hom. Hulle bely Hóm. En omdat hulle bely, het ons die eerste geloofsbelydenis: "Jesus Christus is Here". Die belydenis as daad was eerste. Die belydenis as saak is moontlik omdat mense deur die Woord en Gees van God tot geloof gelei en tot spreke gedwing is. Hieruit maak ons 'n eerste, baie belangrike gevolgtrek- 
king: Belydenis as daad, en daarom ook asof vanselfsprekend die belydenis as gefikseerde saak, het 'n verwysende, getuigende karakter. Dit verwys nooit na homself nie, maar altyd na lets (lemand) wat groter is. Dit is nie soseer 'n konstatering van waarheid nie, as verwysing ná en getuienis ván die Waarheid. Hierdie Waarheid is so groot, dat die belydenis nooit die volheid daarvan kan omvat nie. Hierdie Waarheid kan nooit vasgevang word in één bepaalde formule of definisie nie. Indien dit moontlik sou wees sou dit beteken dat ons oor die Waarheid, en dit is God self, sou beskik. En dit is tog ondenkbaar. God is nog altyd groter en geheimsinniger as wat ons kan dink en sê. Hy het selfs vir die belyer nog altyd 'n verrassing. Daarom kan daar nooit gesê word dat die belydenis (as daad òf saak) die volmaakte en afdoende draer van die Waarheid is nie.

Hiermee samehangende moet gesê word dat die belydenis nie 'n doel in sigself is nie. Die doel daarvan is om iets te getuig aangaande God in sy gang deur die tyd. Die belydenis is daarom in die eerste plek uiting van geloof en nie soseer voorwerp van geloof nie. Hierdie feit moet veral in gedagte gehou word wanneer die woord "belydenis" gebruik word in die sin van 'n "summa" van die leer van die kerk, as die formulering van die essensiële waarheid wat die kerk glo en bely. Die belydenis is nie self die waarheid nie, maar dra die waarheid. Dit is egter altyd prinsipieel moontlik dat 'n waardiger en beter draer van die waarheid na vore sal kom. Die belydenis is immers nie soseer woord nie as antwoord. Dit is 'n antwoord van die kerk op die appél wat gerig word deur die openbaring van God in en deur Jesus Christus.

Op hierdie stadium is dit egter wenslik dat die aandag tog op iets anders gevestig word. In die praktyk funksioneer die gefikseerde belydenis as die grond en bron vir aktiewe belydenis. Dit gebeur selfs waar hierdie saak reg hanteer word, en waar die belydenis (skrif) nie ' $n$ posisie toegeken word wat dit in werklikheid bokant die Skrif verhef as dit wat geglo moet word nie. Hier funksioneer dit in ieder geval as ' $n$ soort filter waardeur die eintlike Waarheid benader en besigtig word. Dat dit onafwendbaar is, sal nog duidelik blyk uit wat hieronder gaan volg. Hier word dit maar net, so in die verbygaan, vermeld ter wille van die volledigheid van die prentjie.

Ons vasstelling op hierdie stadium is in elk geval dat die belydenis nie ' $n$ waarheid in sigself is nie, maar heenwys ná die Waarheid. Dit is antwoord op die Woord en het gevolglik net relatiewe betekenis. Dit is eerstens ' $n$ daad van geloof wat, as gevolg van talle oorwegings, fikseer en òf mondelings òf skriftelik voortgedra word. In ons verdere gesprek moet hierdie vasstelling steeds in gedagte gehou word. 


\section{DOGMATIEK}

Die woord "dogmatiek" is nog nie so lank in ons midde nie, trouens, dit is maar pas in die jaar 1659 vir die eerste keer in sy huidige betekenis gebruik. Die saak wat daardeur aangedui word, is egter so oud soos die kerk self. Dit gaan naamlik om die sistematiese teologie, of te wel die sistematiese ordening van Bybelse materiaal, sodat 'n kerklike leer ontstaan. Die kerklike leer manifesteer homself in dogmas of leerstukke. Die dogmatiek het dus op een of ander manier te maak met die dogmas van die kerk. Op welke wyse hy daarmee te make het, hang af van hoe die kerk die dogmas waardeer.

Die Roomse kerk waardeer die dogmas as openbaringswaarhede. Volgens hulle opvatting beskik hulle, in die onfeilbare leergesag van die kerk, oor die bindende uitleg van die Bybel. Hier is die Bybel nie meer vry nie - staan die Bybel nie meer as 'n vrye outoriteit teenoor die kerk nie. Die kerk het hier die Bybel gevange geneem - hy beskik oor die Woord. Daarom kan die dogma hier geld as 'n openbaringswaarheid, self onfeilbaar en volmaak. In hierdie milieu kan die taak van die dogmatiek dan niks anders wees nie as om die openbaringswaarhede te orden en dit in sy rykdom te deurgrond en uiteen te sit. Hier kan die kerk trots wees op sy besit van die Waarheid, en kan hy dit ook ronduit teenoor die wêreld verklaar: Ons het die Waarheid!

In die Protestantse wêreld funksioneer die dogmatiek heeltemal anders (of immers, behoort dit heel anders te funksioneer), wat die Protestantse beginsel is dat die dogmas nie openbaringswaarhede is nie. Dogmas is niks meer nie as formulerings - menslike formulerings - wat die openbaringswaarheid (en dit is Jesus Christus) net in soverre kan vat en weergee, as wat dit na daardie Waarheid strewe of daarheen op pad is.

Verre daarvandaan dat hier sprake sou wees van afgehandeldheid of finaliteit, is daar juis sprake van 'n onafheid. Pleks van rus, is daar juis sprake van onrus. Dit behoort juis tot die tak van die dogmatiek om voortdurend onrus te stook met die vraag: Is dit wat die kerk leer nog in orde? Is die leer van die kerk nog te vereenselwig met die Waaheid waarheen dit wil wys, en met die geloof waarvan dit uitdrukking wil wees? In die Protestantisme gaan dit nie om wat die kerk by wyse van geopenbaarde waarheid het nie, maar om wat hy glo. In hierdie milieu is dit die taak van die dogmatiek om die wesentlik Christelike telkens weer nuut te sê, en om die dogmas van die verlede hoogstens as toevallige, en deur hulle historiese omstandighede bepaalde, oplossings te waardeer. Natuurlik kan die formulerings van die verlede herhaal word, maar dan net ná kritiese toetsing aan die eintlike kriterium vir die waarheid - die Heilige Skrif as getuienis aangaande die Woord van God. 
Wanneer daar dus hieronder van die dogmatiek sprake is, sal dit in hierdie sin van die woord wees: 'n Kritiese wetenskap wat die reeds verworwe kerklike standpunte herhaaldelik toets aan die Skrif, en, indien moontlik, hierdie reeds verworwe insigte inkorporeer in sý poging om die wesentlik Christelike in sý historiese omstandighede uit te spreek.

\section{DIE VERHOUDING BELYDENIS - DOGMATIEK}

Dat daar 'n uiters noue verbintenis tussen die belydenis van die kerk en sy dogmatiek is, het al uit die voorafgaande begin duidelik word. Die vraag is net van watter aard hierdie verbintenis is. Daar is baie verskillende moontlikhede: òf die belydenis van die kerk is aanleiding tot dogmavorming wat die studieveld van die dogmatiek vorm, ò die dogmatiek kom na vore met nuwe dogmas wat deel word van die kerklike belydenis, òf die belydenis gee aanleiding tot dogmatiese ondersoek wat nuwe dogmavorming tot gevolg het, ò dogmavorming roep nuwe belydenis in die lewe, wat weer nuwe materiaal vir kritiese toetsing aan die dogmatiek verskaf.

Wanneer die verskillende moontlikhede op hierdie manier gekatalogiseer word, word dit duidelik dat hier sprake is van 'n sirkelverbintenis wat net nie gebreek kan word nie. Om tussen hierdie moontlikhede te kies is ' $n$ onmoontlike onderneming. In die praktyk sal dit duidelik blyk dat hierdie moontlikhede mekaar afwissel. Dit sal duidelik word dat die belydenis aanleiding bied tot dogmavorming. Dit sal egter óók duidelik word dat nuwe dogmas die neiging het om, asof vanself, deel te word van die belydenis.

Die verbintenis is egter nog inniger en intiemer. ' $n$ Belydenisuitspraak is al klaar ' $n$ dogmatiese uitspraak! Dit is al waar van die oudste Christologiese belydenis wat aan ons bekend is - Fil 2:11. Wanneer die vroegste kerk uitroep: "Jesus Christus is Here!", is dit meer as 'n dogmatiese uitspraak - dit is ' $n$ belydenis van geloof, aanbidding, verheerliking en afhanklikheid wat uit die hart geruk is. In hierdie formule het die ou kerk sy hele eksistensie uitgestort. Maar - dit was óók 'n dogmatiese uitspraak. Dit sê tog immers iets bepaalds oor Jesus Christus. Dit sê dit só dat dit duidelik moet word dat hierdie die geldende uitspraak oor Jesus is. Dit is met ander woorde ' $n$ afgrensende uitspraak - die belydenis grens hom af teen ánder, nie-geldende uitsprake. Só sit daar dus al van huisuit iets van apologetiek en polemiek in die belydenis. Dit kan nie anders nie. Wanneer die Waarheid jou werklik vasgryp, sodat jy dit móet sê, sal jy dit só sê dat die negering van die halwe waarheid en die leuen daarby ingesluit is.

Die belydenis is al klaar ' $n$ dogmatiese uitspraak. Beteken dit nou 
dat die oerbelydenis: "Jesus Christus is Here", die gevolg was van sistematies-teologiese denke? Dit is die vraag wat ons vervolgens moet ondersoek.

Wanneer Jesus, volgens Mateus 16:17, aan Petrus sê dat sy belydenis van Jesus as die Seun van God nie steun op menslike insig nie, maar op die verhelderende werking van die Gees van God ("dit is nie 'n mens wat dit aan jou geopenbaar het nie, maar my Vader wat in die hemel is"), dwing dit ons om te sê dat die belydenis as geloof, sy oorsprong dank aan die Woord en Gees van God. Maar dit is darem ook nou nie al wat hieroor gesê kan word nie. Hierdie geloof moet eers geartikuleer word voordat dit belydenis is. Hierdie artikulasie vind plaas in taal, met gebruikmaking van woorde en begrippe. Dit vind plaas in ' $n$ bepaalde situasie, binne die grense van die tyd. Daarom is dit menslike werk. Dit kom nie tot stand sonder gebruikmaking van die menslike denkkategorieë nie. Dit impliseer dus intellektuele, sistematiese arbeid - dws dogmatiese arbeid. Laat ons dus herhaal wat hierbo reeds gesê is: Die belydenis is menslike antwoord op die Woord van God. Dit is menslike respons op die goddelike openbaring in Jesus Christus. En dit is nie 'n voorgesêde antwoord of respons nie. Die antwoord is uit en uit mensewerk, maar wakkergeroep deur die daad van God. 'n Voorlopige gevolgtrekking kan gevolglik só lui: Vir sover as wat dit vir ons moontlik is om die gebeure rondom die totstandkoming van die oerbelydenis te peil, lyk dit nie asof hierdie belydenis tot stand sou kon kom, sonder dit wat ons ken as dogmatiese of sistematies - teologiese arbeid nie. Uit die aard van die saak word dan nie verwys na formele teologiese arbeid nie, maar hoogstens na geloofsdenke, wat deur die openbaring in Jesus Christus aan die gang gesit is. Dit sou weinig meer wees as ' $n$ vergelyking tussen die verskynsel Jesus van Nasaret en die heils - en Messiasverwagting wat in die Jodendom geleef het; maar nietemin sistematiese teologie, al was dit dan hoe rudimentêr en onwetenskaplik volgens moderne standaard.

Dit dan wat die verbintenis tussen belydenis en dogmatiek in die geval van die oerbelydenis betref. Dit is onmiskenbaar daar maar tog enigsins vaag en onspesifiek. Wanneer daar egter gekyk word na die gefikseerde belydenis van 'n bepaalde kerk, sien die saak daar heel anders uit. In hierdie verband kan ons aandag gee aan die reformatoriese belydenis soos dit gefikseer het in die belydenisskrifte.

Dit is sonder meer duidelik dat die belydenisskrifte die resultaat is van sistematies-teologiese werksaamheid. Dit behoef nie eers argumentering nie. Die oerbelydenis is deur die kerk, as gevolg van inwendige en uitwendige faktore, en deur middel van die dogmatiek, uitgebou tot daardie gefikseerde belydenis waardeur die kerk nie net sy geloof bely nie, maar waardeur hy hom ook identifiseer. Een ding moet hier net eers duidelik gestel word: Wanneer hier op 
kategoriese wyse gestel word dat hierdie belydenisskrifte die resultaat is van dogmatiese denke, beteken dit nie dat beweer word dat hierdie geskrifte net 'n intellektueel-rasionele grondslag het nie. Natuurlik is dit die geloof van die kerk wat hier aan die woord kom, en die geloof is nie afhanklik van die dogmatiek nie. Die dogmatiek is afhanklik van die geloof - dit is uiteindelik ook niks anders as geloofswerk nie - dit is die intellektuele worsteling van ' $n$ gelowige met daardie Waarheid wat Jesus Christus is, in 'n poging om daardie Waarheid te artikuleer. Om te sê dat die belydenisskrifte die resultaat is van dogmatiese arbeid, is om die aandag weer 'n keer daarop te vestig dat die geloof nie in sy geartikuleerde vorm geopenbaar is nie. Jesus openbaar God en roep tot geloof en dit kos harde en doelgerigte dogmatiese arbeid om hierdie geloof tot spreke te bring.

Die geloof is nie afhanklik van die dogmatiek nie, maar die belydenis van die geloof wél. As geloofsbelydenis verstaan word as die artikulasie van geloof, behoort dit op hierdie stadium duidelik te wees dat dit nie sonder dogmatiese werksaamheid tot stand kan kom nie. Op hierdie stadium van ons ondersoek lyk dit dus moontlik om die volgende logiese verloop te konstrueer: In die eerste plek is daar die openbaring. Die openbaring roep die geloof in die lewe. Geloof dwing die besitter daarvan tot spreke. Spreke veronderstel arbeid aan die kant van die spreker om te kan artikuleer. Die gevolg van dit alles is die belydenis. As ons vanuit ons situasie sou kyk en op simplistiese manier die openbaring gelyk sou stel aan die Heilige Skrif, sou ons die logiese verloop as volg kon teken: In die Heilige Skrif het ons getuienis van die openbaring, dus openbaring, wat die geloof wakkerroep. Die kerk raak, in geloof, met hierdie openbaringsgetuienis aan die worstel. Hierdie worsteling is uiteindelik niks anders nie as sistematies-teologiese arbeid (wat uit die aard van die saak steun op eksegese en hermeneutiek en al die ander Bybelwetenskappe) waarvan die gevolg die geartikuleerde geloof is so as wat dié in die belydenisskrifte van die kerk gevind kan word.

Die saak is egter nie só simplisties nie. Dit word eindeloos ingewikkelder wanneer in gedagte gehou word dat die toegang tot die geloof (dit nou gesien vanuit die ervaringswerklikheid van elke indiwiduele gelowige) hoofsaaklik verkry word aan die hand van hierdie geartikuleerde geloof - hierdie belydenis. Dit is naamlik sonder meer 'n mite dat ons 'n direkte en objektiewe toegang tot die Skrif het. Dit is onmoontlik om die Skrif te lees sonder die bril van die belydenis. Dit is waar, selfs waar iemand doelbewus sal probeer om dit nie te doen nie. Hy doen dit in die negatiewe sin van die woord dan juis. Die feit is dat ons na die Skrif toe gaan met 'n belydenis, ' $n$ belydenis wat al klaar ons geloof gevorm het. Voordat ons immers nog die Bybel optel, glo ons dat ons hier (op een of ander manier) te make het met die Woord van God. Ons het nie 
soiets as ' $n$ onbevange toegang tot die Skrif nie - die belydenis is ons toegang. Die belydenis is die sleutel waarmee ons die geheimenis van die Skrif probeer ontsluit, sodat ons ons geloof daarin herken. Dieselfde is dan egter ook weer waar van die man wat deur 'n ander belydenis gevorm is. Hy kyk deur die bril van sý belydenis, en herken sý geloof in die Skrif. Dit alles is onvermydelik, want die essensie van die Waarheid - dit wat geglo moet word - kom nie onbemiddeld na ons toe nie; dit kom deur bemiddeling van die belydenis. Dit is ' $n$ werklikheid wat ons nie kan negeer nie.

Dat dit ernstige implikasies het vir die "Sola Scriptura" spreek vanself. Hierdie reformatoriese slagspreuk kan gevolglik net gedeeltelik gehandhaaf word, net in soverre as wat daar erken sal word dat ons vandag op die skouers van die kerk van die eeue staan as ons die Bybel lees. In die praktyk geld hierdie slagspreuk in elk geval nog altyd as: Net die Skrif, soos gelees deur die bril van ons belydenis.

Dit het ewe ernstige implikasies vir die dogmatiek. Hierbo is gestel dat dit in die eerste plek die taak van die dogmatiek is om die reeds verworwe standpunte van die kerk (en dit is tog die gefikseerde belydenis) te toets aan die Skrif. Hoe kan hy dit doen, onbevange doen, as hy (as gelowige denkarbeid van die kerk) juis die Waarheid benader deur gebruikmaking van die bril wat hy moet toets? Anders gestel: Hoe kan hier sprake wees van objektiewe wetenskaplikheid as die dogmatiek die belydenis moet gaan toets aan die hand van die Skrif, terwyl hy op ' $n$ bepaalde belydenisgrondslag staan en die Skrif gevolglik dan juis vanuit daardie belydenis en met daardie belydenis benader?

Dit lyk onvermydelik dat ons hier tereg sal kom in ' $n$ hermeneutiese sirkel waaruit daar geen uitkomkans is nie, maar wat inteendeel al nouer en beklemmender word hoe harder jy probeer om jouself daaruit te dink. Hierdie is wesenlik' $n$ probleem wanneer die dogmatiek beskou word as arbeid van die kerk. Dit sê onmiddellik dat hierdie arbeid verrig word vanuit ' $n$ bepaalde gesigspunt en binne die binding van ' $n$ bepaalde belydenis. In die geval van ' $n$ vrye dogmatiek, waar geen belydenisbinding aanvaar word nie, sal die probleem stellig nie so akuut wees nie, en sal die sirkel nie so onverbreekbaar vooorkom nie. 'n Vrye dogmatiek is egter nie 'n oplossing nie. Dit is ' $n$ grotendeels nuttelose onderneming met weinig, indien enige, waarde vir die kerk. Dit kan in elk geval nooit kerklike geloofsbesinning oor die geloof van die kerk wees nie. Wanneer die dogmatiek só waardeer word, as 'n kerklike werksaamheid, is die sirkel onafwendbaar. Dan staan die Skrif sentraal, met die dogmatiek wat die belydenis aan die Skrif toets, maar wat die Skrif lees aan die hand van die belydenis. Dit is die soort sirkel wat kan uitloop op stagnasie. Hierdie prentjie dui op die totstandkoming van ' $n$ teologiese sisteem wat selfs ' $n$ formidabele omvang kan 
hê, maar waarin daar nog net selfbevrugting kan plaasvind. Die gevolg hiervan sal so ' $n$ intelery wees dat mens later met ' $n$ imposante dog steriele nakomeling opgeskeep sal kan sit, heelwaarskynlik heeltemal irrelevant in die wêreld waarin hy hom bevind. Al moontlikheid wat hier nog oorbly is die stigtelike gesprek onderling. Dit is die soort gesprek waarin weinig nuuts ooit gehoor word, maar wat daaruit bestaan dat die bekende altyd weer uitgehaal en blinkgevryf word.

\section{'N VIERDE GROOTHEID}

Daar is egter 'n vierde grootheid wat in hierdie saak ' $n$ rol speel. Tot dusver in hierdie voordrag het hy grotendeels op die agtergrond gestaan. Dit is nou egter tyd dat hy na vore sal kom. Dit is ' $n$ grootheid wat dikwels verag word en weggewys word as irrelevant en ontoelaatbaar in die teologiese gesprek. Myns insiens is dit egter die grootheid wat die doodsheid van bogenoemde sirkel deurbreek, of anders gestel; nie toelaat dat dit daartoe kom nie. Ek praat nou van die situasie. Die situasie deurbreek die sirkel, deurdat dit nuwe antwoorde van die geloof vra. Dit is onmiddellik die stimulus tot nuwe, byderwetse en andersgerigte dogmatiese arbeid, en die vrug hiervan is uiteindelik hernude en miskien selfs nuwe belydenis. Wanneer die situasie sy regmatige plek beklee, sal alle versoeking om van die dogmatiek 'n tydlose en verhewe tydverdryf te maak vedwyn, en sal daar iets van tereg kom dat hierdie werksaamheid van die kerk antwoorde gee op die vraagstukke waarmee die kerk op sy pad deur die wêreld gekonfronteer word.

Dit gaan nie hier om wat normaalweg bekend staan as situasieteologie nie. Dit gaan daarom dat die geloof tot spreke moet kom - moet getuig en bely - binne die situasie waarin die kerk hom bevind. Die kerk kan nie vandag meer net só praat as 2,000 jaar gelede nie, die mense van ons dag verstaan eenvoudig nie meer die taal van destyds nie. Om gehoor te word moet die kerk sy geloof nuut artikuleer en nuut bely. Dit dui dan op dogmatiese werksaamheid wat twee groothede in die oog hou: Die geartikuleerde geloof wat die kerk geboekstaaf het, en waaruit die dogmatiek self leef, aan die een kant (en hier funksioneer die belydenis uitsluitlik as toegang tot die Heilige Skrif), met aan die ander kant die lewenssituasie waarin die aktiewe belydenis van die kerk, die waarheid van God hoorbaar moet maak.

Waar die klem in hierdie saak moet lê, spreek nagenoeg vanself. Wanneer die klemtoon sou lê by die situasie, sou die dogmatiek verword tot politieke wetenskap, sosiologie of iets dergeliks, en sal die belydenis verskraal en die waarheid verduister word. Wanneer 
die klem egter by die belydenis van die kerk lê, kan verwag word dat die dogmatiek die kerk nie daartoe sal verlei om die nuwe te sê ('n nuwe wat 'n nuwe waarheid wil wees en miskien juis daarom die leuen is) nie, maar daartoe sal lei om die ou Waarheid (wat die enigste waarheid is) nuut te sê. In hierdie konteks sal nuwe belydenis dan beteken dat die geloof, wat die kerk nog altyd bely het en vroeër telkens geartikuleer het, weer 'n keer geartikuleer word, om in 'n ander situasie te spreek, sodat dit nie dalk stil word omdat die mense die vroeëre artikulasie nie meer verstaan nie. Om tot hierdie nuwe (beter: hernude) belydenis te kom, het die geloof die dogmatiek nodig. Om rigting aan te dui in hierdie nuwe situasie waarin die geloof tot spreke moet kom, is die dogmatiek afhanklik van die reeds vroeër geartikuleerde geloof, met ander woorde die belydenis. Dit is dus amper soos ' $n$ simbiose. Die een kan die ander een nie mis nie. So word dit dan moontlik dat die nuwe belydenis die oue nie ophef nie maar opneem. En dit is ook die beste manier om die geloofserfenis van die verlede te bewaar - deur nie daarin te verstar nie.

\section{Literatuur}

1. Die Religion in Geschichte und Gegenwart.

2. Ott, Heinrich, Die Antwort des Glaubens, Kreuz Verlag, Stuugart-Berlin, 1973.

3. Polman, ADR, Onze Nederlandsche Geloofsbelijdenis, T. Wever, Franeker.

4. Van Niftrik, GC, Kleine Dogmatiek, GF Callenbach, Nijkerk, $1961^{5}$.

5. Van Ruler, AA, Plaats en Functie der Belijdenis in de Kerk, Visie en Vaart, Amsterdam, 1947.

6. Van Ruler, AA, Hoe Functioneert de Belijdenis?, Theologisch Werk, Deel 6 GF Callenbach, Nijkerk, 1973.

7. Weber, Otto, Grundlagen der Dogmatik, Neukirchener Verlag, Neukirchen Vluyn, 1963. 